\title{
Comparative Study on the Performance of China's Economy Hotel with Different Chain Organization Modes
}

\section{Zhang Tao, Jia Binbin \\ School Of Management, Hefei University of Technology, Hefei 230000, China}

\begin{abstract}
Economy hotels are not only a service industry with huge consumption potential and franchising widely used, but also is outstanding in the hotel industry. However, affected by the rapid rise in rent and labor costs, severe homogeneous competition and other reasons, hotels are facing development bottlenecks. Based on the perspective of corporate chain organizational model, the CCR model and BCC model of data envelopment analysis (DEA) are used to comparative analysis the operating efficiency of 12 economy hotels in 2013.The results show that in 2013: the overall efficiency of the Chinese economy hotel is not high, but the average pure technical efficiency at a high level; the performance differences between different organizational models economy hotel chain significantly, in addition to the little difference of pure technical efficiency, are both predominantly company-owned chain>plural form>predominantly franchised chain.
\end{abstract}

KEYWORDS: Economy Hotel; Chain Organization Mode; Efficiency; DEA

\section{Introduction}

In the 1990s, the concept of economy hotel began to enter China. In 1996, Shanghai Jinjiang group launched the first economy hotel brand of China: JinJiang Inn. Later since the twenty-first century, a variety of economy hotel brands had developed rapidly like bamboo shoots after a spring rain. However, the new "Tourism Law" was implemented formally in 2013, plus the scant domestic demand after the financial crisis, which has brought great impact to both the luxury hotels and the economy hotels. The expansion rate of economy hotel straight camp shop began to slow down and the occupancy rate also declined, with a depression situation. Therefore, scientific and reasonable measure and analysis of performance of economy hotel has become an important issue that the operators and researchers are commonly concerned about.

The most widely used methods on hotel performance is data envelopment analysis (DEA). Early in 2000, Anderson and Scott once applied DEA-BCC and DEA-CCR model to assess the business performance of 48 tourist hotels in America, and the result showed that the average performance of all the hotels is 0.42 . In recent years, DEA model also began to spread up in China. Wang Feiqing used DEA method to measure the comprehensive technical efficiency, pure technical efficiency and scale efficiency of 50 tourist hotels in Taiwan, and it was concluded that the efficiency of chain hotels is higher than that of non-chain hotels.

However, there is lack of research on enterprise micro-level with DEA method, so is efficiency evaluation of economy hotel, especially from the perspective of different 
chain organization types. In this context, in this paper, from the perspective of chain organization type, we use DEA model to compare and analyze the resource allocation efficiency, technical efficiency and scale efficiency of 12 China's economy hotels in 2013, and put forward some countermeasures to improve the efficiency and business performance of economy hotels.

\section{Research Methods and Variable Selection}

\section{A. DEA Theoretical Model}

DEA is a kind of linear programming method, proposed by Charnes, Cooper and Rhodes, based on Farell's research foundation on production efficiency evaluation. Through the comprehensive analysis of sample input and output data, it obtains the numerical values of comprehensive efficiency of each decision unit and sorts them, to determine whether the decision making units are effective or not. Meanwhile, DEA model has advantages in solving the multiple-input and multiple-output problems.

There are many kinds of DEA model, including the initial CCR model, and the current BCC, ST and FG models as well, among which CCR model and BCC model are most widely used. In this paper, we apply the investment-oriented CCR model and BCC model to describe the comprehensive technical efficiency, pure technical efficiency and scale efficiency of economy hotels.

Suppose there are $\mathrm{n}$ economy hotels (DMU), each of which using $m$ sorts of input factors and s sorts of output factors; $X_{\mathrm{ij}}$ refers to the number $\mathrm{i}$ input of the number $\mathrm{j}$ hotel; $\mathrm{Y}_{\mathrm{fj}}$ refers to the number $r$ output of the number $\mathrm{j}$ hotel. $\left(\mathrm{X}_{\mathrm{i}}, \mathrm{Y}_{\mathrm{j}}\right)$ refers to the number $\mathrm{j}$ hotel $\left(\mathrm{DMU}_{\mathrm{j}}\right) . \mathrm{V}=(\mathrm{V} 1$, $\mathrm{V} 2, \ldots, \mathrm{Vm})^{\mathrm{T}}$ and $\mathrm{U}=(\mathrm{U} 1, \mathrm{U} 2, \ldots, \mathrm{Um})^{\mathrm{T}}$ refers to the corresponding weight coefficients. We can always choose appropriate weights $\mathrm{v}$ and $\mathrm{u}$, to make $h j \leqslant 1, j=1,2, \cdots, n$. Then construct the original plan optimization model as follow:

$$
\begin{array}{ll}
\max & \frac{u^{T} Y_{0}}{v^{T} X_{0}} \\
\text { s.t } & \frac{u^{T} Y_{0}}{v^{T} X_{0}} \leq 1, j=1, \cdots, n, \\
& u \geq 0, v \geq 0
\end{array}
$$

Apply Charnes-Cooper conversion, introducing the slack variables $\mathrm{S}^{+}$and $\mathrm{S}^{-}$, and non-Archimedean infinitesimal $\varepsilon$; add convexity

constraint of weights: $\sum^{n} \lambda_{j}=1$, and obtain the DEA model based on inputs $-\mathrm{BC}^{2}$ model $\left(\mathrm{D}_{2}:\right)$ :

$$
\begin{array}{ll}
\min & {\left[\theta-\varepsilon\left(e^{\top T} S^{-}+e^{T} S^{+}\right)\right]} \\
\text {s.t } & \sum_{j=1}^{n} X_{j} \lambda_{j}+S^{-}=\theta X_{0}, \\
& \sum_{j=1}^{n} Y_{j} \lambda_{j}-S^{+}=Y_{0}, \\
& \lambda_{j} \geq 0, j=1, \cdots, n \\
& S^{-} \geq 0, S^{+} \geq 0
\end{array}
$$

In the formula, $\hat{e}^{T}=(1,1, \ldots, 1) \in E_{m}, e^{T}=(1,1, \ldots, 1) \in \mathrm{E}_{s}, \varepsilon$ is non-Archimedean infinitesimal. With $\mathrm{BC}^{2}$ model $\left(\mathrm{D}_{2}\right.$ :) we can judge whether the observed decision making unit has technical efficiency or not: that is, suppose $\varepsilon$ as non-Archimedean infinitesimal, and the optimal solutions of linear programming problem $\mathrm{D}_{2}$ is $\lambda^{0}, s^{-0}, s^{+0}, \theta^{0}$; if $\theta^{0}=1$, and $s^{-0}=0, s^{+0}=0$, then the decision making unit $\mathrm{DMU}_{\mathrm{jn}}$ is effective of DEA $\left(\mathrm{BC}_{2}\right)$. 


\section{B. Variable Selection and Data Source}

For variable selection, compliance with the standard of different year operation, enterprise character and chain organization mode, we regard the 12 economy hotels as decision making units, as shown in Table 1:

Table 1. Data Description of 12 Economy Hotels

\begin{tabular}{|c|c|c|c|c|c|c|c|c|c|c|}
\hline Name & Group & $\begin{array}{l}\text { Begi } \\
\mathrm{n} \\
\text { time }\end{array}$ & $\begin{array}{l}\text { Operati } \\
\text { on } \\
\text { duratio } \\
\mathrm{n}\end{array}$ & $\begin{array}{l}\text { Room } \\
\text { numb } \\
\text { er }\end{array}$ & $\begin{array}{l}\text { Total } \\
\text { branc } \\
\mathrm{h}\end{array}$ & $\begin{array}{l}\mathrm{PC} \\
\mathrm{O}\end{array}$ & $\begin{array}{l}\text { Organizati } \\
\text { on type }\end{array}$ & $\begin{array}{l}\text { Mark } \\
\text { et } \\
\text { share }\end{array}$ & $\begin{array}{l}\text { Managem } \\
\text { ent Fee }\end{array}$ & MBI \\
\hline $\begin{array}{l}\text { Home } \\
\text { Inns }\end{array}$ & $\begin{array}{l}\text { Home Inn } \\
\text { group }\end{array}$ & $\begin{array}{c}200 \\
2\end{array}$ & 12 & $\begin{array}{c}19645 \\
8\end{array}$ & 1784 & $\begin{array}{c}0.3 \\
9\end{array}$ & PFC & $\begin{array}{c}17.26 \\
\%\end{array}$ & $6 \%$ & $\begin{array}{c}112.2 \\
8\end{array}$ \\
\hline $\begin{array}{l}\text { JinJiang } \\
\text { Inn }\end{array}$ & $\begin{array}{l}\text { Jinjiang } \\
\text { Internatio } \\
\text { nal Hotel } \\
\text { Group }\end{array}$ & $\begin{array}{c}199 \\
6\end{array}$ & 18 & 87724 & 700 & $\begin{array}{c}0.3 \\
4\end{array}$ & PFC & $\begin{array}{c}7.71 \\
\%\end{array}$ & $4.5 \%$ & $\begin{array}{c}97.6 \\
2\end{array}$ \\
\hline Hanting & $\begin{array}{l}\text { China } \\
\text { live Hotel } \\
\text { Group }\end{array}$ & $\begin{array}{c}200 \\
5\end{array}$ & 9 & $\begin{array}{c}13074 \\
7\end{array}$ & 1226 & $\begin{array}{c}0.4 \\
6\end{array}$ & PFC & $\begin{array}{c}11.49 \\
\%\end{array}$ & $5 \%$ & $\begin{array}{c}85.3 \\
2\end{array}$ \\
\hline $\begin{array}{l}7 \text { Days } \\
\text { Inn }\end{array}$ & $\begin{array}{l}\text { Platinum } \\
\text { Tao Hotel } \\
\text { Group }\end{array}$ & $\begin{array}{c}200 \\
5\end{array}$ & 9 & $\begin{array}{c}16173 \\
9\end{array}$ & 1683 & $\begin{array}{c}0.3 \\
2\end{array}$ & PFC & $\begin{array}{c}14.21 \\
\%\end{array}$ & $7 \%$ & $\begin{array}{c}70.5 \\
6\end{array}$ \\
\hline $\begin{array}{l}\text { GreenTr } \\
\text { ee }\end{array}$ & $\begin{array}{l}\text { GreenTre } \\
\mathrm{e} \quad \text { Inn } \\
\text { Hotel } \\
\text { Group }\end{array}$ & $\begin{array}{c}200 \\
4\end{array}$ & 10 & 81608 & 906 & $\begin{array}{c}0.0 \\
6\end{array}$ & DFC & $\begin{array}{c}7.17 \\
\%\end{array}$ & $5 \%$ & $\begin{array}{c}55.6 \\
1\end{array}$ \\
\hline Podinns & $\begin{array}{l}\text { Sumitom } \\
\text { o Hotel } \\
\text { Hangzhou }\end{array}$ & $\begin{array}{c}200 \\
7\end{array}$ & 7 & 15132 & 207 & $\begin{array}{c}0.4 \\
7\end{array}$ & PFC & $\begin{array}{c}1.33 \\
\%\end{array}$ & $5 \%$ & $\begin{array}{c}25.6 \\
2\end{array}$ \\
\hline $\begin{array}{l}\text { Super } 8 \\
\text { Hotel }\end{array}$ & $\begin{array}{ll}\text { Super } & 8 \\
\text { Hotel } & \end{array}$ & $\begin{array}{c}200 \\
4\end{array}$ & 10 & 79800 & 532 & $\begin{array}{c}0.0 \\
2\end{array}$ & DFC & $\begin{array}{c}5.61 \\
\%\end{array}$ & $5.6 \%$ & $\begin{array}{c}24.6 \\
5\end{array}$ \\
\hline $\begin{array}{l}\text { Motel } \\
168\end{array}$ & $\begin{array}{l}\text { Home Inn } \\
\text { group }\end{array}$ & $\begin{array}{c}200 \\
2\end{array}$ & 12 & 52889 & 378 & $\begin{array}{c}0.4 \\
3\end{array}$ & PFC & $\begin{array}{c}4.65 \\
\%\end{array}$ & $6 \%$ & $\begin{array}{c}20.1 \\
6\end{array}$ \\
\hline Orange & $\begin{array}{l}\text { Orange } \\
\text { Hotel } \\
\text { group }\end{array}$ & $\begin{array}{c}200 \\
6\end{array}$ & 8 & 1546 & 14 & 1 & DCC & $\begin{array}{c}0.14 \\
\%\end{array}$ & I & $\begin{array}{c}18.0 \\
7\end{array}$ \\
\hline Ibis & $\begin{array}{l}\text { Accor } \\
\text { hotel } \\
\text { group }\end{array}$ & $\begin{array}{c}201 \\
0\end{array}$ & 4 & 15000 & 67 & $\begin{array}{c}0.7 \\
0\end{array}$ & DCC & $\begin{array}{c}1.31 \\
\%\end{array}$ & $6.5 \%$ & $\begin{array}{c}13.2 \\
3\end{array}$ \\
\hline $\begin{array}{l}\text { Thanky } \\
\text { ou }\end{array}$ & $\begin{array}{l}\text { Thankyou } \\
\text { Hotel }\end{array}$ & $\begin{array}{c}200 \\
9\end{array}$ & 5 & 16521 & 301 & $\begin{array}{c}0.2 \\
1\end{array}$ & DFC & $\begin{array}{c}1.45 \\
\%\end{array}$ & $4.5 \%$ & 9.63 \\
\hline $\begin{array}{l}\text { City } \\
\text { Express }\end{array}$ & $\begin{array}{l}\text { City } \\
\text { Express } \\
\text { Hotel } \\
\text { Group }\end{array}$ & $\begin{array}{c}200 \\
6\end{array}$ & 8 & 13914 & 149 & $\begin{array}{c}0.3 \\
2\end{array}$ & PFC & $\begin{array}{c}1.22 \\
\%\end{array}$ & $6 \%$ & 4.96 \\
\hline
\end{tabular}


Considering DEA method needs to focus on the correlation between inputs and outputs, and variable selection in previous research on hotels, we finally select the index of hotel operation duration in1, hotel room number in2 and royalties in3. In output index selection, we select Meadin Brand Index (MBI, weighted average of influence of the user, media and industry) as output variable. In order to overcome the effects of the economic crisis and other factors outside interference on research, we choose 2013 as the data time. The data in this study mainly comes from 2013 Chinese 120 top franchise chain by Chinese Chain
Management Association, 2014 China Hotel Chain Development and Investment Report by China Hotel Association, and Meadin hotel industry portal.

\section{Results}

Use DEAP2.1 software to make CCR model and BCC model arithmetic of sample data from the perspective of input, and obtain the comprehensive technical efficiency (CRSTE), pure technical efficiency (VRSTE) and scale efficiency (SE), as shown in Table 2:

Table 2. Efficiency Value Difference of 12 Economy Hotels

\begin{tabular}{|c|c|c|c|c|c|c|}
\hline \multirow{2}{*}{ Name } & \multicolumn{2}{|c|}{ CRSTE } & \multicolumn{2}{|c|}{ VRSTE } & \multirow{2}{*}{ SE } & \multirow{2}{*}{$\begin{array}{l}\text { Returns } \\
\text { to scale }\end{array}$} \\
\hline & Score & Benchmarking & Score & Benchmarking & & \\
\hline $\begin{array}{l}\text { 1. Home } \\
\text { Inns }\end{array}$ & 1.000 & (0) & 1.000 & (0) & 1.000 & Constant \\
\hline $\begin{array}{l}\text { 2. JinJiang } \\
\text { Inn }\end{array}$ & 1.000 & (5) & 1.000 & (1) & 1.000 & Constant \\
\hline 3. Hanting & 1.000 & (3) & 1.000 & (4) & 1.000 & Constant \\
\hline $\begin{array}{l}\text { 4. } 7 \text { Day } \\
\text { Inn }\end{array}$ & 0.827 & 3 & 0.886 & $3 ; 10$ & 0.933 & Increment \\
\hline $\begin{array}{c}5 . \\
\text { GreenTree }\end{array}$ & 0.817 & $2 ; 3$ & 0.859 & $2 ; 3 ; 6 ; 9$ & 0.951 & Increment \\
\hline 6. Podinns & 1.000 & (4) & 1.000 & (1) & 1.000 & Constant \\
\hline $\begin{array}{l}\text { 7. Super } 8 \\
\text { Hotel }\end{array}$ & 0.458 & $2 ; 3$ & 0.910 & $3 ; 9 ; 10$ & 0.504 & Increment \\
\hline 8. Motel 168 & 0.328 & $2 ; 6$ & 0.526 & $3 ; 9 ; 10$ & 0.624 & Increment \\
\hline 9. Orange & 1.000 & (1) & 1.000 & (4) & 1.000 & Constant \\
\hline 10. Ibis & 0.705 & $2 ; 6$ & 1.000 & (4) & 0.705 & Increment \\
\hline $\begin{array}{c}11 . \\
\text { Thankyou }\end{array}$ & 0.437 & $2 ; 6$ & 1.000 & (0) & 0.437 & Increment \\
\hline $\begin{array}{l}\text { 12. City } \\
\text { Express }\end{array}$ & 0.185 & $6 ; 9$ & 0.697 & $9 ; 10$ & 0.265 & Increment \\
\hline Average & 0.730 & I & 0.907 & I & 0.785 & I \\
\hline
\end{tabular}




\section{A. Overall Efficiency Analysis}

The results show that, the overall technical efficiency and scale efficiency of the economy hotels are relatively low, with the average comprehensive technical efficiency, pure technical efficiency and scale efficiency respectively are $0.730,0.907$ and 0.785 . The comprehensive technical efficiency, pure technical efficiency and scale efficiency of Home Inns, JinJiang Inn, Hanting, Podinns and Orange are all 1 , which are more efficient than the other seven hotels. This proves that these five hotels have made full use of resources in 2013, and got the maximum output with the existing investment.

7 Day Inn, GreenTree, Super 8, Motel 168 and City Express are pure technical inefficient and scale inefficient as well. Among them, scale efficiency of 7 Day Inn and GreenTree are very high, and technical inefficiency is mainly pure technical inefficiency, so it requires managers to improve production technology and management level, so as to increase the utilization capacity of existing resources; however, scale efficiency of Super 8 Hotel, Motel 168 and City Express are very low, and in the stage of increasing returns to scale. Therefore, for these three hotels, they not only need to improve their management levels, but also need to make use of hotel's effective resources and adjust their input, to improve the scale efficiency.

Finally, the economy hotels that pure technical efficiency is 1 and scale inefficient are Ibis and Thankyou. The pure technical efficiency of 1 right reflects Ibis' pursuit of brand and server; scale efficiency of 0.705 illustrates that Ibis would better accelerate the rate of expansion in china, so as to achieve economies of scale. Similarly, as the bright younger generation of economy hotel,
Thankyou is the fastest growing hotel in 2013 in China, with pure technical efficiency of 1 . The Possible reason is that Thankyou is orientated as super economy hotel, so customers' requirements for quality and service are not so high as that of economy hotels. Its scale efficiency is only 0.437 , that is to say, because it entered the hotel industry later, and investment in rooms number is too less, leading to increase of returns to scale. Therefore, it is necessary to increase investment to achieve effective of scale.

\section{B. Efficiency Difference between Hotels of Different Chain Organization Mode}

In this paper, we are trying to analyze and compare economy hotels' efficiency from the perspective of different chain organization types, so firstly we need to classify and define the chain types of organization. Since the development of franchise, foreign scholars have summarized its organization types as three categories: chartered dominant mode, direct dominant mode and composite mode. Considering that franchise in China started later than foreign countries, we classify the organization types as: chartered dominant mode DFC (PCO less than 25\%), composite mode PFC (25\% 70\%) and direct dominant mode DCC (PCO more than 70\%).

Classify the 12 economy hotels above, and obtain their efficiency differences, as shown in Table 3. Pure technical efficiency of direct dominant mode is 1 , while average pure technical efficiency of chartered dominant mode and composite mode is respectively 0.923 and 0.873 , which show that they respectively need to decline about $8 \%$ and $13 \%$ to improve their efficiency. In addition, the pure technical efficiency is high because after the financial crisis, most hotels have improved internal management and rationally made use of the 
available resources. From the scale efficiency perspective, it is almost equivalent of direct dominant mode and composite mode, which are respectively 0.853 and 0.832 , much higher than chartered dominant mode. Scale efficiency of chartered dominant mode is the lowest, because this kind of economy hotels is in early stage of development, and still need through the franchise to quickly complete nationwide layout. From the comprehensive technical efficiency perspective, direct dominant mode> composite mode> chartered dominant mode, chartered dominant mode is only 0.571 , which means that it still has $43 \%$ promotion space. As shown in Figure 1, we can see that the efficiency of direct dominant mode is higher than chartered dominant mode and composite mode, which proves the importance of straight battalion inn in the expansion of the chain. No matter rapid expansion of the chartered dominant mode, or robust expansion of the composite mode, all need to pay attention to ensure that the proportion of straight battalion inn.

Table 3. Organizational Type Efficiency Score Differences

\begin{tabular}{|c|c|c|c|c|c|c|}
\hline $\begin{array}{l}\text { Efficiency } \\
\text { Score }\end{array}$ & $\begin{array}{c}\text { Organization } \\
\text { Type }\end{array}$ & Number & Average & $\begin{array}{l}\text { Standard } \\
\text { deviation }\end{array}$ & Minimum & Maximum \\
\hline \multirow{4}{*}{$\begin{array}{l}\text { Comprehensive } \\
\text { technical } \\
\text { efficiency }\end{array}$} & $\begin{array}{l}\text { Chartered } \\
\text { dominant }\end{array}$ & 3 & 0.571 & 0.174 & 0.437 & 0.817 \\
\hline & $\begin{array}{l}\text { Composite } \\
\text { mode }\end{array}$ & 7 & 0.763 & 0.328 & 0.185 & 1.000 \\
\hline & $\begin{array}{c}\text { Direct } \\
\text { dominant }\end{array}$ & 2 & 0.853 & 0.147 & 0.705 & 1.000 \\
\hline & Total & 12 & 0.730 & 0.289 & 0.185 & 1.000 \\
\hline \multirow{4}{*}{$\begin{array}{c}\text { Pure technical } \\
\text { efficiency }\end{array}$} & $\begin{array}{l}\text { Chartered } \\
\text { dominant }\end{array}$ & 3 & 0.923 & 0.058 & 0.859 & 1.000 \\
\hline & $\begin{array}{l}\text { Composite } \\
\text { mode }\end{array}$ & 7 & 0.873 & 0.176 & 0.526 & 1.000 \\
\hline & $\begin{array}{c}\text { Direct } \\
\text { dominant }\end{array}$ & 2 & 1.000 & 0.000 & 1.000 & 1.000 \\
\hline & Total & 12 & 0.907 & 0.145 & 0.526 & 1.000 \\
\hline \multirow{4}{*}{$\begin{array}{c}\text { Scale } \\
\text { efficiency }\end{array}$} & $\begin{array}{l}\text { Chartered } \\
\text { dominant }\end{array}$ & 3 & 0.630 & 0.228 & 0.437 & 0.951 \\
\hline & $\begin{array}{l}\text { Composite } \\
\text { mode }\end{array}$ & 7 & 0.832 & 0.264 & 0.265 & 1.000 \\
\hline & $\begin{array}{c}\text { Direct } \\
\text { dominant }\end{array}$ & 2 & 0.853 & 0.147 & 0.705 & 1.000 \\
\hline & Total & 12 & 0.785 & 0.256 & 0.265 & 1.000 \\
\hline
\end{tabular}




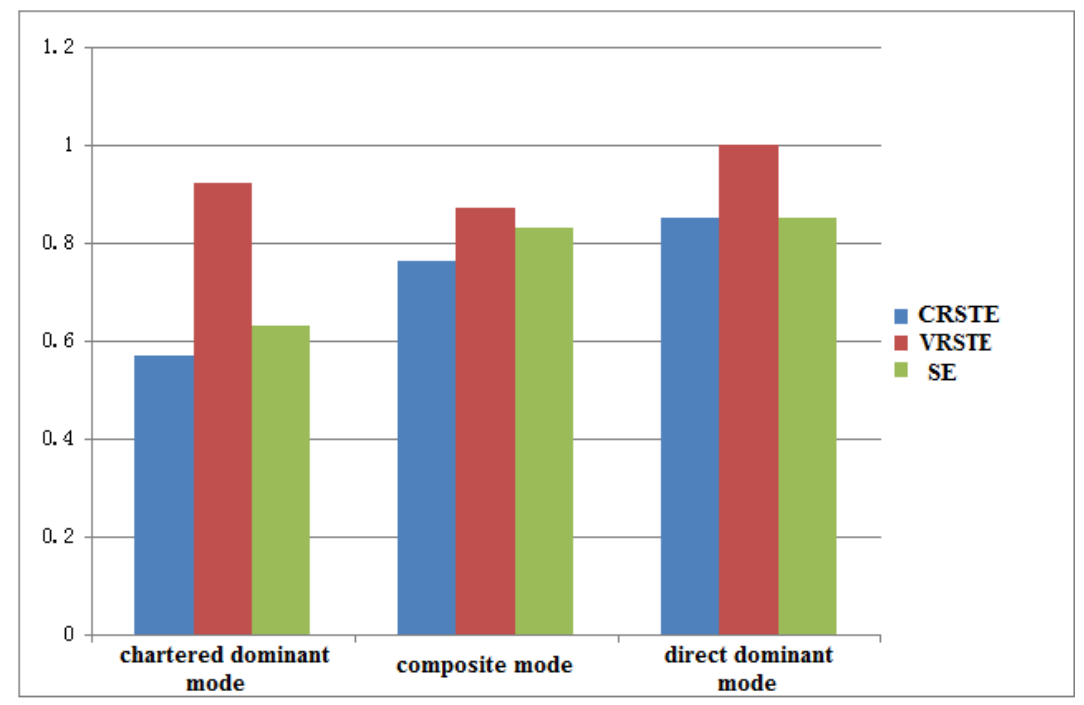

Figure 1. Efficiency Comparison of Different Chain Organization Mode Hotels

\section{Benchmarking of Economy Hotel}

In table 2, it also provides the benchmarking enterprises of low-efficiency hotel, and the reference times of benchmarking enterprises by other decision making units. From the comprehensive technical efficiency perspective, the benchmarking economy hotels include: JinJiang Inn (five times as a benchmark), Podinns (four times as a benchmark), Hanting (three times as a benchmark), and Orange (once as a benchmark). Three of them are composite mode, while one of them is direct dominant mode.

However, from the pure technical efficiency perspective, that is, simple taking hotel management efficiency into account, he benchmarking economy hotels include: Hanting, Orange, Ibis (four times as a benchmark), JinJiang Inn and Podinns (once as a benchmark). Three of them are composite mode, while two of them are direct dominant mode.

\section{Conclusions}

In this study, we use DEA model to synthetically evaluate and analyze the efficiency of China's 12 economy hotels in 2013, and focus on comparison of efficiency differences between economy hotels of different chain organizational modes, and obtain the following conclusions: (1) the average comprehensive technical efficiency, pure technical efficiency and scale efficiency of economy hotels have a certain gap with the optimal efficiency. five of all twelve hotel are in the state of pure technical inefficient and scale inefficient, so they still need to be improved in management level and investment ratio. (2) The efficiency differences between economy hotels of different chain organizational modes are significant. In addition to the pure technical efficiency, the sequence is direct dominant mode> composite mode> chartered dominant mode.

Combined with the empirical results, here we propose some measures and suggestions to enhance the efficiency of Chinese economy hotel as follow: (1) For the economy hotels that do not achieve economies of scale, they should adopt the forms of reducing the franchise threshold, acquisition or re-OEM, to achieve economies of scale. (2) For the pure technical inefficient economy hotels, faced with the 
seriousness of the homogenization, managers tap their own strengths to reposition themselves, such as hotel's hardware and software facilities, art uniqueness in decoration level, etc. to improve the hotel occupancy rate and performance through the core competitiveness. In addition, In the era of Internet data, economy hotels can create a network of sales channels by advanced technology (such as mobile APP) to improve the utilization of hotel's existing resources, to control marketing costs and improve the management level and service quality. (3) Since efficiency of direct dominant mode is Relatively high, so we recommend that when develop new stores, economy hotels can increase the proportion of straight battalion inn within the reasonable scope, in order to avoid the increase of difficulty to maintain the brand because of the high proportion of franchise.

\section{REFERENCE:}

[1] Botti,L., Briec, W. and Cliquet,G.Plural forms versus franchiseandcompany-ownedsystems: a DEA approach of hotel chain performance[J].Omega,2009,37(3):566-578..

[2] de Jorge Moreno, J. and Sanz-Triguero, M. Estimating technical efficiency andbootstrapping
Malmquist indices: analysis of Spanish retail sector[J].International Journalof Retail \& Distribution Management,2011,39(4):272-288.

[3] El Akremi, A., Perrigot, R. and Piot-Lepetit, I.Examining the drivers for franchisedchains performance through the lens of the dynamic capabilities approach[J].Journal ofSmall Business Management,2013,53(1):145-165.

[4] Hwang S N, Chang T Y.Using Data Envelopment Analysis to Measure Hotel ManagerialEfficeencyChange in Taiwan[J].Tourism Management,2003,24(4):357-369.

[5] Keh, H.T. and Chu, S.Retail productivity and scale economies at the firm level: a DEAapproach[J].Omega, 2003,31(2): 75-82.

[6] Perrigot, R., Cliquet, G. and Piot-Lepetit, I.Plural form chain and efficiency: insights fromthe French hotel chains and the DEA methodology[J].European Management Journal,2009,27(4): 268-280.

[7] Piot-Lepetit, I., Perrigot, R. and Cliquet, G.Organizational form andefficiency of franchise chains[J].International Journal of Retail \&Distribution Management,2014,42(7): 671-684. 